\title{
Estimated carbon stored on some landscape forests in South East Sulawesi
}

\begin{abstract}
Rosmarlinasiah
Department of Forestry, Faculty of Forestry and Environmental Science, Halu Oleo University,Kendari, South East Sulawesi, Indonesia.
\end{abstract}

\begin{abstract}
Carbon stored in several forest landscapes in Southeast Sulawesi such as the Jati stand on the People's Forest, Pine stands in Protected Forest, Mangrove Forest vegetation, Natural vegetation of urban forest, and Campus Forest show the weight of carbon stored per hectare different from one vegetation to another. The objective of this research is to know the biomass and the amount of carbon stored up (levels of the tree, pole, stakes), the lower plants, litter and nekromassa in various forest landscape in Southeast Sulawesi. Biomass is obtained through the use of allometric equations (plants on the surface), and measures the wet weight and dry weight (bottom plants, woody necromassa and non-woody). Furthermore, the estimated amount of carbon stored. The results showed Pinus stand (Pinus mercusii) carbon stored 65,992 tons $\mathrm{ha}^{-1}$, stand Teak (Tectona grandis) 36.213 tons $\mathrm{ha}^{-1}$, Mangrove vegetation (Bruguiera gymnorrhiza, Lumnitzera racemosa, Rhizophora sp, Sonneratia alba, and Avicennia alba) 68.12 tons $\mathrm{ha}^{-1}$, natural vegetation Forest City 50.01 tons hat ${ }^{-1}$ natural vegetation Forest Campus 98.18 tons $\mathrm{ha}^{-1}$. The availability of carbon estimation information in various forest landscapes can be used as supporting data for REDD + programs aimed at addressing climate issues.
\end{abstract}

Keywords-Biomass, Carbon estimation, Forest landscape, Vegetation.

\section{INTRODUCTION}

Forest landscape is a description of land cover both within forest area and outside forest area in the form of forest and non forest. This can be described in terms of the area of land cover. Area of land cover in and outside the forest area of Southeast Sulawesi Province 3,638,000,7 Ha. Where land cover area in forest area is $1,943,000,8 \mathrm{Ha}$ and not forest area 1,694,000,9 $\mathrm{Ha}$ [1].

REDD + activities are one of the mitigation or mitigation measures caused by climate change in the forestry sector by reducing emissions from deforestation, degradation and conservation, SFM and increased carbon stocks.
[2], [3], [4] that, there are 5 carbon sources to be measured through field measurements; above ground biomass, below ground biomass, dead wood, litter, and soil. While the source of carbon to 6 that is harvested wood products (harvested wood products) has not been taken into account. Carbon needs to be measured because basically carbon stock is the amount of carbon stored in vegetation, other biomass in the soil.Efforts to reduce GHG concentrations in the atmosphere (emissions) is to reduce the release of $\mathrm{CO}_{2}$ into the air. Therefore, the amount of $\mathrm{CO}_{2}$ in the air must be controlled by increasing the amount of $\mathrm{CO}_{2}$ uptake by the plants as much as possible and suppressing the emission release as low as possible. [2]Thus maintaining the integrity of natural forests, planting trees on agricultural lands and protecting peatlands is essential to reduce excessive amounts of $\mathrm{CO}_{2}$ in the air.

\section{MATERIALS AND METHODS}

\subsection{Materials}

The results of the research took place in the teak plantation forest (Tectona grandis Lf)) in North Buton District, Mangrove Forest in Latompa village, Maligano sub-district, Muna district, Pinus stands (Pinus mercusii) in NangaNanga Protection Forest Kendari City, Natural Forest Vegetation in Kecamatan Baruga Kendari City, and natural vegetation Forest Campus in District Baruga Kendari City.

\subsection{Methods}

This research method using Desk Study approach by summarizing the results of existing carbon estimation research that took place in 2012 until 2015, and also collects materials and other information from literature related to climate issues. The results are then studied in the form of qualitative and quantitative descriptive.

\section{STATISTICAL ANALYSIS}

Biomass calculations use some allometric equations (Table 1), and estimates of carbon stored in several forest landscapes in Southeast Sulawesi use the equation ie $\mathrm{C}=$ BK (ton / ha) x 0.46 [2] 
Calculations Biomass used in the results of research, can be

seen in Table 1 below:

Table.1: Biomass Calculation Methods of several forest landscapes in Southeast Sulawesi

\begin{tabular}{|c|c|c|c|c|c|}
\hline \multirow{3}{*}{$\begin{array}{c}\text { Forest } \\
\text { Landscap } \\
\mathrm{e}\end{array}$} & \multirow{3}{*}{$\begin{array}{c}\text { Type of } \\
\text { Vegetation }\end{array}$} & \multicolumn{4}{|c|}{ Biomass Calculation } \\
\hline & & \multirow{2}{*}{$\begin{array}{c}\text { Top plants } \\
\text { (allometric equations) }\end{array}$} & \multirow[t]{2}{*}{ Lower plants } & \multicolumn{2}{|c|}{ Nekromassa } \\
\hline & & & & Woody & Not woody \\
\hline $\begin{array}{l}\text { Protected } \\
\text { forest }\end{array}$ & $\begin{array}{l}\text { Pine stands } \\
\text { (Pinus merkusii) }\end{array}$ & $\mathrm{Y}=0,0936 \int \mathrm{D}^{2,432}[5]$ & $\begin{array}{r}\mathrm{BK}=\left(\mathrm{BK}_{\mathrm{sc}} / \mathrm{BB}_{\mathrm{sc}}\right. \\
\quad) \times \mathrm{BB}_{\mathrm{tot}}[6]\end{array}$ & $\begin{array}{l}\mathrm{Y}=\pi \cdot \int \cdot H \cdot \mathrm{D}^{2} / 4 \\
0 \\
{[6]}\end{array}$ & $\begin{array}{l}\mathrm{BK}=\left(\mathrm{BK}_{\mathrm{sc}} / \mathrm{BB}\right. \\
\left.{ }_{\mathrm{sc}}\right) \times \mathrm{BB}_{\text {tot }} \\
{[6]}\end{array}$ \\
\hline $\begin{array}{l}\text { Forest } \\
\text { City }\end{array}$ & Natural vegetation & $\begin{array}{l}\text { Tree branched: [5] } \mathrm{Y}=0,11 \int \mathrm{D}^{2,62} \\
\text { Not Branching:[6] } \mathrm{Y}=\pi . \int . H . \mathrm{D}^{2} / 40 \\
\text { Pillars and Stakes:[7] } \\
\mathrm{Y}=10^{0,535+\log 10(\mathrm{BA})}\end{array}$ & $\begin{array}{r}\mathrm{BK}=\left(\mathrm{BK}_{\mathrm{sc}} / \mathrm{BB}_{\mathrm{sc}}\right. \\
\quad) \times \mathrm{BB}_{\text {tot }}[6]\end{array}$ & $\begin{array}{l}\mathrm{Y}=\pi \cdot \int \cdot \mathrm{H} \cdot \mathrm{D}^{2} / \\
40[6]\end{array}$ & $\begin{array}{l}\mathrm{BK}=\left(\mathrm{BK}_{\mathrm{sc}} / \mathrm{BB}\right. \\
\mathrm{sc}) \times \mathrm{BB}_{\text {tot }} \\
{[6]}\end{array}$ \\
\hline $\begin{array}{l}\text { Campus } \\
\text { Forest }\end{array}$ & Natural vegetation & $\begin{array}{l}\text { Tree branched:[5] } \mathrm{Y}=0,11 \int \mathrm{D}^{2,62} \\
\text { Not Branching: }[6] \\
\mathrm{Y}=\pi . \int . H . \mathrm{D}^{2} / 40 \\
\text { Pillars and Stakes:[7] } \mathrm{Y}=10^{-} \\
0,535+\log 10(\mathrm{BA})\end{array}$ & $\begin{array}{r}\mathrm{BK}=\left(\mathrm{BK}_{\mathrm{sc}} / \mathrm{BB}_{\mathrm{sc}}\right. \\
\quad) \times \mathrm{BB}_{\text {tot }}[6]\end{array}$ & $\begin{array}{l}\mathrm{Y}=\pi \cdot \int \cdot \mathrm{H} \cdot \mathrm{D}^{2} / \\
40[6]\end{array}$ & $\begin{array}{l}\mathrm{BK}=\left(\mathrm{BK}_{\mathrm{sc}} / \mathrm{BB}\right. \\
\mathrm{sc}) \times \mathrm{BB}_{\text {tot }} \\
{[6]}\end{array}$ \\
\hline $\begin{array}{l}\text { Forest } \\
\text { People }\end{array}$ & $\begin{array}{l}\text { Teak Plant } \\
\text { (Tectona grandis } \\
\text { Lf) }\end{array}$ & {$[8] \mathrm{Y}=0,08842 \mathrm{D}^{2,6014}$} & - & - & - \\
\hline $\begin{array}{l}\text { Mangrove } \\
\text { forest }\end{array}$ & $\begin{array}{l}\text { Standby } \\
\text { Mangrove }\end{array}$ & $\begin{array}{l}\text { Trunk: [9] } \\
\text { Y=0,079211DBH }{ }^{2,470895} \\
\text { Branch:[9] } \\
Y=0,481575 \times 1,24628^{\text {DBH }} \\
\text { Leaf: }[9] \\
Y=0,171711 \times 1,96367^{\text {DBH }}\end{array}$ & - & - & - \\
\hline
\end{tabular}

\section{RESULTS AND DISCUSSION}

\subsection{Pine stands in Protected Forest}

The Protected Forest has an area of 307.54 ha. [10] Study on Pine stands (Pinus mercusii) in Nanga-Nanga Protected Forest, from 5 point sampling plots can be explained that the number of individual Pinus (Pinus mercusii) averages 1045 individuals $\mathrm{ha}^{-1}$, and diameter averages $21 \mathrm{~cm}$. Mean of biomassa on Pine Plant Various Levels of vegetation 159.286 ton ha- and carbon deposit 65.992 ton ha ${ }^{-1}$.

\subsection{Natural Vegetation in City Forest}

[11] Forest City Baruga is one of the city forest in Kendari City is established with an area of 3 ha with natural environmental conditions so that the management must be able to meet one of the ecological functions as a carbon sink. [12] The results study show that the number of individual vegetation in City Forest, from 8 point sampling that the number of individual of vegetation (tree, poles, stakes, seedling and puppies) averages 4781.25 individuals $\mathrm{ha}^{-1}$. Mean of biomassa natural vegetation in city forest 108.719 ton ha ${ }^{-1}$, and carbon deposit 50.01 ton $\mathrm{ha}^{-1}$. Upper plants, plants and necromassas only have a total stored carbon of 50.01 tons $\mathrm{ha}^{-1}$. This is possible because the city forest with natural vegetation is located within the city of Kendari, making it very susceptible to disruptions that could lead to forest degradation.

\subsection{Natural Vegetation in Campus Forests}

Haluoleo University Campus Forest is a natural vegetation located within the campus in Kecamatan Kambu Kendari with an area of $58.96 \mathrm{Ha}$. The research results [13] explain that the campus forest, there are 81 species of plants, 65 families, from 4975 specimens. The family has the largest number of species of Myrtaceae, Euphorbiaceae and Fabaceae.

The tabulation of the results of biomass and carbon (C) calculations on each plot of forest in Halu Oleo University Campus can be seen in Table 2 [14].

\subsection{Teak stands in the People's Forest}

The observed teak stands are located in other areas of use (APL) with the status of land owned by some communities in the sub-district of Labuan, Wakorumba Sub-district, North Buton Regency, Southeast Sulawesi. The width of the Teak stand (Tectona grandis Lf) is 20.42 ha and the age of Teak ranges from 5 years to 16 years. [15] The stand of Teak in Labuan Sub-district People's Forest has an average 
density of 1025 trees ha $^{-1}$ at the age of 5 years and age 6 to 16 years. Based on the table 3 below shows that, the more the age of the teak stand (Tectona grandis Lf), the more carbon deposits are stored in the stands.

Carbon stored in Teak (Tectona grandis Lf) shows the increasing age of teak, increasing the amount of carbon stored, where at the age of 16 years there are 78.96 tons ha ${ }^{-1}$ of stored carbon, while the age of 5 years 16.89 tons ha-1. If the average is from the age of 5 to 16 years, then it is assumed that every age has 36.213 tons of carbon stored ha 1 .

\subsection{Carbon Stored in Mangrove Forest}

The area of mangrove forest in Latompa Village, Maligano Sub-district, Muna Regency, Southeast Sulawesi Province $160 \mathrm{Ha}$. The types of compilers Mangrove Forest consists of Bruguiera gymnorrhiza, Lumnitzera racemosa, Rhizophora sp., Sonneratia alba, and Avicennia alba [16]. Based on the results [16] study, the amount of biomass and carbon storage in each mangrove species in Latompa Village, Biomassa 148.13 ton $\mathrm{ha}^{-1}$ and Carbon storage 68.12 ton $\mathrm{ha}^{-1}$. The total amount of carbon stored is only about 68,12 ton per hectare. . [17] Land use system consisting of trees with species with low wood density values, the tree biomass will be lower when compared to land with species with high wood density values.

\subsection{Recapitulation of Estimated Saved Carbon}

Carbon stored in several landscapes of forests in Southeast Sulawesi are protected forests, urban forests, campus forests, community forests and mangrove forests show different amounts of stored carbon. This can be seen from the structure of the constituent vegetation, the vegetation type, the age of the plant, the stand site, and the degree of damage to the forest landscape. The more layered growth rate in a stretch (the level of trees, poles, stakes, seedlings), the higher the carbon content stored in the vegetation. Vegetation consisting of various types has a higher stored carbon than a one species vegetation. This can be seen in Table 4 below.

\section{CONCLUSIONS AND RECOMMENDATIONS}

Forest landscapes in Southeast Sulawesi have different amounts of stored carbon. The largest amounts of stored carbon among forest landscape observed in upper plants, under plants and necromassas, respectively were in the campus forests of 98.181 tons $\mathrm{ha}^{-1}$, then in protected forests (Pinus stands), and urban forest (natural vegetation) of 50, 01 tons $\mathrm{ha}^{-1}$. Forest landscapes in Southeast Sulawesi have different amounts of stored carbon. The largest amount of stored carbonaceous forests, under plants and necromassas, respectively were in the campus forests of 98.181 tons / ha, then in protected forests (Pinus stands), and urban forest (natural vegetation) of 50, 01 ton / ha. While the forest landscape that only observes carbon stored in the upper plants, the highest in the mangrove forest (68.12 tons ha $\mathrm{h}^{-1}$ ), and the lowest in the forest (Teak plant) with 36.213 tons $\mathrm{ha}^{-1}$ of stored carbon. The amount of carbon stored in each forest landscape is affected by the structure of the stand, the number of vegetation constituents, the age of the plant, the site where the vegetation develops, and the extent of damage. The natural vegetation composed of complete stand structures (trees, masts, saplings and seedlings) tends to have higher amounts of carbon stored, compared to one standing layer alone. Natural vegetation of mixed species also tends to have higher amounts of stored carbon than vegetation consisting of only one type of constituent. Carbon stored in plants will be higher, as the age of the plant increases. In addition, mangrove vegetation with tidal habitats (tidal vegetation), although a natural vegetation but has a lower amount of carbon stored than in the natural vegetation habitat on land.

Carbon stored in plants will be higher, as the age of the plant increases. In addition, mangrove vegetation with tidal habitats (tidal vegetation), although a natural vegetation but has a lower amount of carbon stored than in the natural vegetation habitat on land. The People's Forest Program is very good at reducing carbon emissions, but it is best to use multi-species cropping patterns with layered structures.

\section{REFERENCES}

[1] Ministry of Forestry. (2012). Forestry Statistics of Indonesia 2011. Ministry of Forestry. ISBN: 979-606073-6 Jakarta.

[2] Hairiah, K and Rahayu, S. (2007). Practical Guidelines Measurement. Carbon Saved. In Various Use of Land. Bogor. World Agroforestry CenterICRAF, SEA Regional Office, University of Brawijaya, Unibraw, Indonesia, $77 \mathrm{p}$.

[3] IPCC. [2008]. 2006 IPCC Guidelines for National Greenhouse Gas Inventories-A primer, Prepared by the National Greenhouse Gas Inventories Programme, Eggleston H.S., Miwa K., Srivastava N. And Tanabe K. (eds). Published: IGES, Japan.

[4] GOFC-GOLD. (2010). A sourebook of methods and procedures for monitoring and reporting anthropogeni greenhouse gas emissions and removals aused by deforestation, gains and losses of carbon stocks in forests remaining forest, and forestation. GOFC- 
GOLD Report version COP 16-1, (GOFC-GOLD Project Office, Natural Resources Canada, Alberta, Canada).

[5] Ketterings QM., Coe R., van Noordwijk M., Ambaqau Y., dan Palm CA. (2001). Reducing Uncertainty in The Use of Allometric Biomass Equations For Predicting Above-Ground Tree Biomass in Mixed Secondary Forests. Forest Ecology and Management. 146:199-209.

[6] Hairiah, K., Ekadinata A., Sari RR., And Rahayu, S. (2011). Measurement of Carbon Reserves: from land level to landscape. Practical hints. Second edition. Bogor, World Agroforestry Center, ICRAF SEA Regional Office, University of Brawijaya (UB), Malang. Indonesia.

[7] Brown and Sandra. (1997). Estimating Biomass and Biomass Change of Tropical Forests: a Primer. (FAO Forestry Paper - 134). FAO, Rome.

[8] Warman. (2010). Estimation of Carbon Absorption in Teak Stack (Tectona grandish) in Laea District of South Konawe Regency. Kendari. Essay. Department of Forestry. Faculty of Agriculture, University of Haluoleo. Kendari. Not Published.

[9] Chukwamdeel, Jirasak and Anunsiriwat, A. (1997). Biomass Estimation for Avicennia alba at Changwat Samut Songkram. http://www.dnp.go.th

[10]Habrina, S.N. (2015). Hydrological Studies and Estimation of Carbon Reserves on Pine Stakes (Pinus mercusii L.f) in Nanga-Nanga Protected Forest. Essay. Department of Forestry Faculty of Forestry and Environmental Sciences Haluoleo University. Kendari. Not published.
[11] Mayor Decree of Kendari No 10 Year (2008). About Protection And Management of Forest Area, City Forest And Green Open Space In The Region of Kendari City

[12] Yulianti, L. (2015). Estimated Carbon Deposits (C) Vegetation in Forest City Baruga Kendari City. Essay. Department of Forestry Faculty of Forestry and Environmental Sciences Halu Oleo University. Kendari. Not Published.

[13] Gandi, Indra. (2009). Analysis of Vegetation Composition of New Campus Andounohu Haluoleo University Kendari Sulawesi. Bachelor's Thesis, Faculty of Agriculture, Haluoleo University. Kendari. Not Published.

[14] Hamidin, (2013). Biomass and Carbon Estimates (C) Stored in Forest Campus Universitas Halu oleo. Essay. Department of Forestry, Faculty of Agriculture, Haluoleo University. Kendari. Not published.

[15] Alsa, F.D. (2014). Biomass and Carbon Estimates Stored on Teak Stands (Tectona grandis Lf) People's Forest in Labuan Sub-District Wakarumba Subdistrict of North Buton Regency. Essay. Department of Forestry Faculty of Forestry and Environmental Sciences Haluoleo University. Kendari. Not published.

[16] Viana, R.A. (2015). Estimated Carbon Saved At Tree Level in Mangrove Forest Village of Latompa, Maligano District. Essay. Department of Forestry Faculty of Forestry and Environmental Sciences Halu Oleo University. Kendari. Not in Publish.

[17] Rahayu, S., Lusiana, B., Van Noordwijk, M. (2007). Estimation of Carbon Reserves Above Surface Land on Various Land Use Systems in Nunukan District, East Kalimantan. World Agroforestry Center. Bogor.

Table.2: Calculation of biomass and carbon $(C)$ in each plot of forest in Haluoleo University campus

\begin{tabular}{lcc}
\hline Observation Grid & $\begin{array}{c}\text { Average Total Biomass } \\
(\text { tons ha }\end{array}$ & $\begin{array}{c}\text { Average Total Carbon } \\
\left(\text { tons ha }^{-1}\right)\end{array}$ \\
\hline Tree $(\mathrm{d}>30 \mathrm{~cm})$ & 151.3385 & 69.615710 \\
Tree $(\mathrm{d} 5-30 \mathrm{~cm})$ & 50.4429 & 23.203734 \\
Lower Plants & 2.9401 & 1.352446 \\
Nekromassa Wood & 3.77065 & 1.734499 \\
Nekromassa Not Woody or & 4.9444 & 2.274424 \\
Rough litter & 213.4365 & \multirow{2}{*}{98.180813} \\
\hline Amount & &
\end{tabular}


Table.3: Biomass and carbon stored at each age of teak stand (Tectona grandis) in Labuan Sub-district People's Forest

\begin{tabular}{|c|c|c|c|c|c|}
\hline \multirow{2}{*}{$\begin{array}{c}\text { Age } \\
\text { Teak } \\
\text { (Year) }\end{array}$} & \multicolumn{2}{|c|}{ Stand Teak } & \multicolumn{2}{|c|}{ Litter under teak stands } & \multirow{2}{*}{$\begin{array}{c}\text { Saved Carbon } \\
\text { Amount } \\
(\text { tons ha-1) }\end{array}$} \\
\hline & $\begin{array}{l}\text { Biomassa } \\
\left.\left(\text { tons }^{-1}\right)^{-1}\right)\end{array}$ & $\begin{array}{c}\text { Carbon Saved } \\
\left(\text { tons } \mathrm{ha}^{-1}\right)\end{array}$ & $\begin{array}{l}\text { Biomassa } \\
\left(\text { tons ha }^{-1}\right)\end{array}$ & $\begin{array}{c}\text { Carbon Saved } \\
\left(\text { tons } \mathrm{ha}^{-1}\right)\end{array}$ & \\
\hline 5 & 26,34 & 13,17 & 7,43 & 3,72 & 16,89 \\
\hline 6 & 32,26 & 16,13 & 7,66 & 3,83 & 19,96 \\
\hline 7 & 36,21 & 18,11 & 8,22 & 4,11 & 22,22 \\
\hline 8 & 43,13 & 21,57 & 8,15 & 4,08 & 25,65 \\
\hline 9 & 49,40 & 24,70 & 8,35 & 4,17 & 28,87 \\
\hline 10 & 56,47 & 28,23 & 10,44 & 5,22 & 33,45 \\
\hline 11 & 73,08 & 36,54 & 11,03 & 5,51 & 42,05 \\
\hline 13 & 102,84 & 51,42 & 12,91 & 6.45 & 57.87 \\
\hline 16 & 140,56 & 70,28 & 17,36 & 8.68 & 78.96 \\
\hline
\end{tabular}

Average

36.213

Table.4: Recapitulation of stored carbon estimates in various forest landscapes in Southeast Sulawesi.

\begin{tabular}{|c|c|c|c|c|c|c|}
\hline \multirow[t]{3}{*}{ Forest Landscape } & \multirow{3}{*}{$\begin{array}{c}\text { Type } \\
\text { Vegetation }\end{array}$} & \multicolumn{5}{|c|}{ Estimated Saved Carbon (tons ha ${ }^{-1}$ ) } \\
\hline & & \multirow{2}{*}{$\begin{array}{c}\text { Plant } \\
\text { on }\end{array}$} & \multirow{2}{*}{$\begin{array}{l}\text { Lower } \\
\text { plants }\end{array}$} & \multicolumn{2}{|c|}{ Nekromassa } & \multirow{2}{*}{$\begin{array}{c}\text { amount (tons } \\
\text { ha }^{-1} \text { ) }\end{array}$} \\
\hline & & & & Woody & Not woody & \\
\hline Protected forest & $\begin{array}{l}\text { Pine stands } \\
\text { (Pinus merkusii) }\end{array}$ & 64,047 & 0,181 & 1,515 & 0,249 & 65,992 \\
\hline $\begin{array}{l}\text { Forest } \\
\text { City }\end{array}$ & Natural vegetation & 47,962 & 0,259 & 0,541 & 1,248 & 50,010 \\
\hline Campus Forest & Natural vegetation & 92,819 & 1,352 & 1,734 & 2,274 & 98,181 \\
\hline Forest People & $\begin{array}{l}\text { Teak Plant } \\
\text { (Tectona grandis Lf) }\end{array}$ & 36,213 & - & - & - & 36,213 \\
\hline Mangrove forest & $\begin{array}{l}\text { Standby } \\
\text { Mangrove }\end{array}$ & 68,12 & - & - & - & 68,12 \\
\hline
\end{tabular}

